\title{
Fostering Interactions at Public Open Spaces. The Role of Physical Interface in Facilitating User Interactions in the UAE
}

\author{
Arushi Malhotra, Ranjana Dobriyal \\ Manipal Academy of Higher Education, United Arab Emirates \\ arushi.malhotra@manipaldubai.com | ranjana.dobriyal@manipaldubai.com
}

\begin{abstract}
Over the past few decades, the importance of public open spaces has been substantially increased due to rapid urbanization and developments. Likewise, cities and communities in the Arab world are also going through urban transformation; driven by the global context in which cities are being reshaped along with the modernization of urban planning themes. Over the last 15 years, Dubai has emerged as one of the world's fastest growing cities. It has been associated with the desire to build tall buildings as a statement of modernity, globalization, and economic prosperity, which lead to a rapid growth in population; breeding many environmental and urban planning challenges. Hasty urbanization, demographic, and economic growth alongside land privatization process has progressively changed the nature and theme of public open spaces within the United Arab Emirates (UAE) in turn creates a gap between social life and community urban planning. The regeneration of public open spaces in cities of the UAE is a major issue as multiple factors must be taken into consideration during the design stages. This paper aims at understanding the role of physical interface of the public open spaces in context of UAE and its transformation over the years. These spaces act as a catalyst which accelerate this transformation of urban scenario and there by citizens life. Open places play an important role for bringing people closer and act as a socio-cultural entity for the sake of improving social life and interactivity. Social well-being arises from a sense of security, belonging, familiarity, support, cohesion, and integration of social groups, based on respect for different cultures, traditions, and backgrounds. Hence this research analyses the influence of such tangible and intangible elements in the public open spaces, through which the social interaction happens and offers unprecedented experience to the users, visitors and urban community alike.
\end{abstract}

Keywords: Arab cities, social interaction, urban phenomenology, architecting interactions, redefining urban spaces

To cite this article:

Malhotra, A., Dobriyal, R. (202I) Fostering Interactions at Public Open Spaces. The Role of Physical Interface in Facilitating User Interactions in the UAE, The Journal of Public Space, 6(I), $167-$ I84, DOI I0.3289I/jps.v6il.I337

This article has been double blind peer reviewed and accepted for publication in The Journal of Public Space. (c) This work is licensed under a Creative Commons Attribution - Non Commercial 4.0 International License https://creativecommons.org/licenses/by-nc/4.0/ 


\section{Introduction}

Cities are more than just buildings and structures. They are a complex blend of natural, built, economic and social components. Over the past two centuries, more public open spaces have been developed in European and North American cities to build the interaction between people and their communities (Gruen, 1960). Consequently, several other countries around the world have followed this trend and pattern of urban development, and similarly, cities in the Middle East have endeavoured to do so. However, to accomplish this, lot of planning and numerous factors need to be taken into consideration.

When we talk about public open space it is important to understand its meaning in relation to two other terms which are associated with it, that is, open space and green space. In most of the cases both these terms seem to be used loosely and interchangeably. In this research the term 'Public open spaces' refers to all the spaces that are characterized under 'public use' of the city which are open and accessible to all the citizens regardless of gender, race, ethnicity, age or socio-economic level of the individual. According to definition of PS by Charter of Public Space it should be free from any profit motive and enjoyable to all (Garau at al., 20I3). These spaces encourage the meeting of new cultures, fostering the public's understanding of interconnections and there by extending ways for the socio-cultural interaction within a unique platform. The realm in and around these spaces, the amenities provided within its built environment along with their location have a huge impact on the user interactions that take place in the physical interface of these sites.

There are several alternative ways to classify these public open spaces, based on ownership; government restrictions on usage; and accessibility of the space to the city dwellers. (Tibbalds, 2004) Gehl studied European cities with an aim to understand the relation between outdoor activities and the physical environments, such as the architecture, pathways, and landscaping. Communal open spaces, regardless of size, function and type, are generally considered essential facilitators of healthy social interaction (Gehl, 1987).

Various literature studies on public realm indicates how most of the Middle Eastern cities over the past two centuries suffered urban degradation in terms of its public open spaces (Yarwood, 20I I). Modernization and industrialization resulted in progressively disconnected neighbourhoods with declining popularity of urban squares (a public place where citizens assembled, worked, shopped, or simply mingled lost its relevance).

\section{Significance and scope of the study}

This study is to signify the role of physical interface of a space for promoting interactions among its users in context of public open spaces in the UAE which are open and accessible to all the city dwellers as well as tourists regardless of gender, race, ethnicity, age or socio-economic level of the individual.

With the help of case studies this research also examines the effectiveness of developing public open spaces of different hierarchy in the UAE and its relevance in providing the context for fostering interactions among its users. In addition, this research focuses on the concept of new urbanism in the UAE by integrating public spaces as a sociocultural entity within the existing as well as upcoming urban fabric for the sake of improving social life and developing vibrant environment. 
The research is largely based on observations drawn by case studies and no real sampling was pursued; hence, the findings of the research are purely qualitative in nature. However, the case studies were carried out by the authors not just from academic perspective but also as city dwellers who are a frequent user of these public open spaces and understands its relationship with the city.

\section{Research methodology}

The paper aims at understanding the role of physical space in encouraging user interactions in the context of public open spaces. The study relies on theoretical analysis, observations and critical assessments of public open spaces based on existing factors and principles that are known to foster interactions in the physical realm. The research presented here starts with understanding the theories related to human interactions followed by qualitative analysis of public open spaces of different hierarchy at the level of city, community, and neighbourhood, in the UAE. The research also focuses on the rhythms of public life in UAE with the aim of understanding how these public spaces developed, evolved, transformed and are understood as well as used over the decades.

\section{Interactivity, interaction and space}

It is first important to understand the difference between Interaction and interactivity. Interaction is a combination of two words 'inter' and 'action' which means action happening between two entities whereas interactivity is affiliated with technology and digital world. We live in a physical world with predominantly physical interactions. Thus, space acts as a physical interface for the interactions.

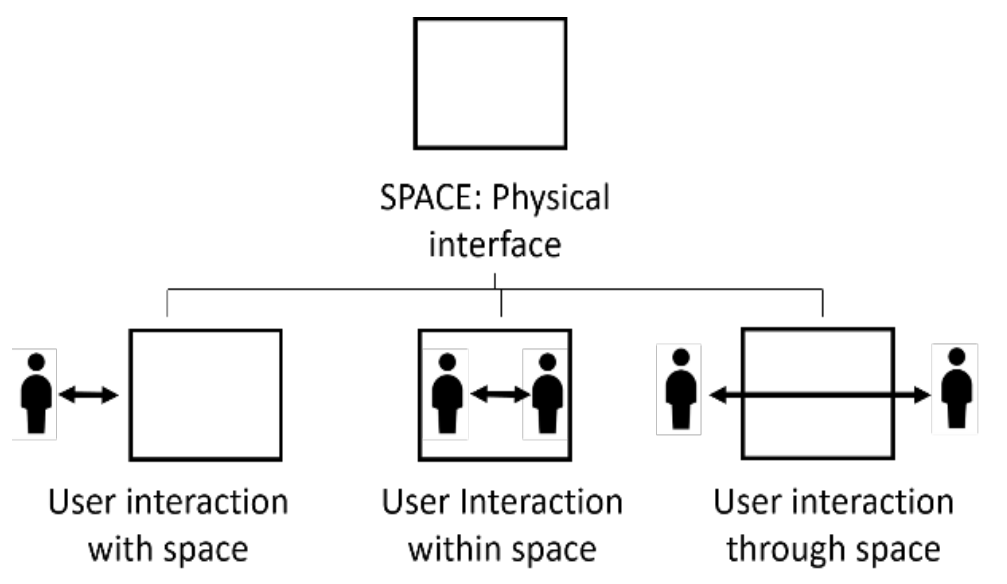

Figure I. Different types of interactions in a space (Source: Author generated illustration)

These interactions can be broadly categorized in three different categories (Hughes, 2017):

a. Interaction between users and space

b. User interactions within the space

c. User interactions through the space

Now whatever the interactions are, or whichever user is involved in it, the space thus becomes the context for interaction, thus giving meaning to it. 


\section{Theoretical background}

A) Principles for interaction

Based on the literature studies, the basic principles which can be identified to promote interaction in a physical interface are (but not limited to) Proximity, Diversity, built functionality and Interaction Nodes. Theodore Newcomb first documented the effect of proximity in his study of the acquaintance process, which demonstrated how people who interact and live close to each other are more likely to develop a relationship. Similarly, Diversity in the user group brings in an array of ideas and ideologies, thus, in turn sparking interest for interactions. Whereas Build functionalities also play a crucial role by creating spaces that have more than one function in it. These in turn has a potential of developing as nodes and Interaction points; which are accessible by a diverse user group; and act as common hubs for interaction. Apart from these principles there are various other factors that further helps in promoting interaction in open spaces. The matrix below shows a relationship between these factors and principles which in turn help fostering interactions in a physical interface.

\begin{tabular}{|l|l|l|l|l|}
\hline PRINCIPLES & Proximity & Diversity & $\begin{array}{c}\text { Built } \\
\text { functionality }\end{array}$ & $\begin{array}{c}\text { Interaction } \\
\text { Nodes }\end{array}$ \\
\hline FACTORS & & & & \\
\hline Accessibility and Proximity & & & & \\
\hline Visual connectivity & & & & \\
\hline Eye level design & & & & \\
\hline Lighting & & & & \\
\hline Multipurpose and multi-functional \\
spaces
\end{tabular}

Table I. Matrix showing the relationship between various factors and principles of interaction (Source: Author generated).

I) Connecting people: The design should have spaces which allow people to approach one another. Apart from physical connectivity, visual connectivity also plays a key role in this.

2)Accessibility and inclusivity: Spaces which are easily accessible and connects different functional areas and user group acts as interaction nodes within the space.

3) Building facades: This factor revolves around openness \& connections, by creating transparent and seamless structures which aid to building visual connections that help user not just to interact with the spaces within the structure but with its surroundings as well. 
4)Creating multipurpose and multifunctional spaces: By creating spaces which have more than one function helps in attracting a greater number of users to it and hence acts as common nodes for interactions.

5)Facilitate the unexpected: Creating elements of surprise in the design gives the user common topics to interact.

6) Eye- level design: This deals with the scale of spaces and the connections/ flow of spaces from one function area to another. Creating eye level designs help create engaging user experiences.

7) Daylight: Reflecting, illuminating, inviting atmosphere helps promote interactions.

8) Informal spaces: Designed spaces which are informal in nature helps users to be comfortable and relaxed.

9) Comfort: This includes both physical and psychological comfort of the users along with light, colors, materials, textures, and furniture and building amenities.

10) Social Inclusion: The design should facilitate civic participation, social mixing and evoke a sense of belonging to its users.

B) Human interaction theory

According to (Dewey, 2003) in general there are two levels of human interaction. The first one is symbolic interaction, which is uniquely human and second, non-symbolic interaction, which is shared with infrahuman. The basic reason for human interaction according to (Dewey, 2003) which is associated with moral conduct, was the active connectedness of human beings with one another, which is characterized by their "mutual intertwined activities" such as desire, beliefs, judgment, satisfaction and dissatisfaction. Human interaction then is influenced by individual need towards the environment and how the perceived benefits might influence negatively or positively are based on the self-judgment. Thus, it is vital to know about the society and the people needs and preferences (Maslow, 1954) provides a good example for identification of the basic needs and creates a foundation for the same.

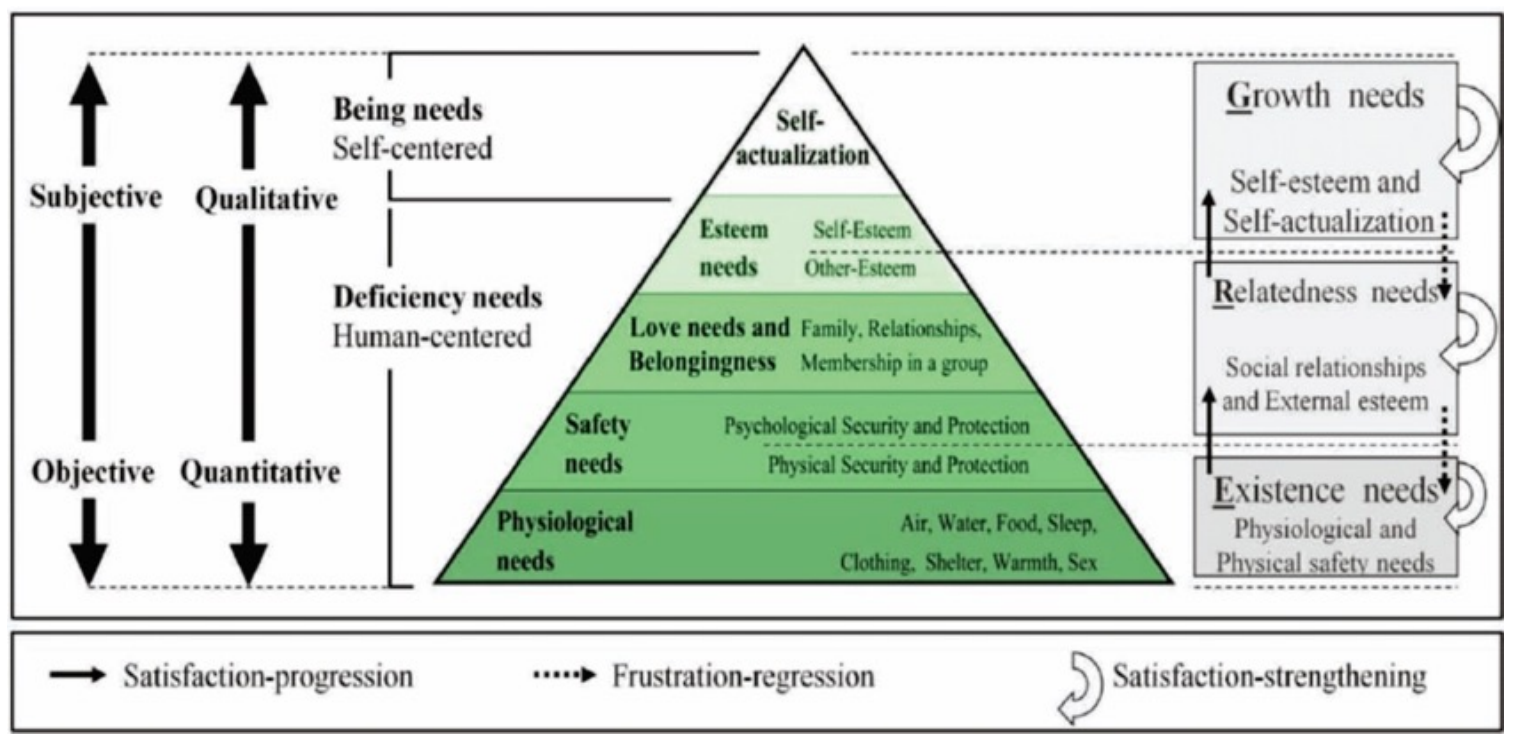

Figure 2. Maslow Hierarchy of Human Interaction Needs. Source: (Maslow, 1954)

C) Theory of phenomenology

Phenomenology demonstrated in architecture is the manipulation of space, material, and light and shadow to create a memorable encounter through an impact on the human senses. This theory promotes the integration of sensory perception as a function of a 
built form. This in turn creates an experience that is beyond tangible, but rather abstract, both in observation as well as perception. An analysis of this aesthetic through interpretation of its qualitative elements and the exploration of case studies by phenomenological theorists, Alberto Pérez-Gómez, Peter Zumthor and Steven Holl, as supportive evidence highlights its fundamental characteristics as a theory, in contrast to a more rationalist design approach (Holl, 2007).

The architecture and design of the space influences the community by incorporating human activity with adapted site context, organized programmatic and interstitial space, and exploration of material. As defined by theorist Vernon Bourke, rationalism is a theory in which the criterion of the truth is not sensory but intellectual and deductive. (Bourke, 1962) Rationalism produces a layered system of scientific reduction, whereas phenomenology delivers layers of sensory details such as emotion informed by design features of light and shadow, material and spatial perception. A new interpretation of functionality within design exists in the phenomenological construct. Architecture is designed to serve the needs of human activity; therefore, creates a relationship between human senses and the building to transform emotion and perception. Christian Norberg- Schulz stresses that the environment influences human beings, and this implies that the purpose of architecture transcends the definition given by early functionalism (Norberg-Schulz, 1980).

Phenomenology is the function of quality. In phenomenology, space is determined by the development of fluid, flexible space and the utilization of interstitial space. Steven Holl elaborates on an architectural synthesis in the book, Questions of Perception, suggesting, foreground, middle ground, and distant view, together with all the subjective qualities of material and light, form the basis of "complete perception. (Holl, 2007) This establishes the necessity for place making through sensory observance. Material is the tactile form of phenomenology that facilitates memory. Light and shadow create a playful interaction of colour, texture and related emotion associated to the space. The contrast between these can be sharp or blurry depending on the desired effect. This strategy can create depth and display texture and is one of the strongest design features in phenomenology. Thus, Phenomenology becomes an evident way to establish the urban Semiology of orientation in a psyche-sociological way of understanding how a space is experienced and lived by its inhabitants. (Mounin, 1980)Hence the imagination of users which is generated through spatial communication is basically the experience of movement, which is delivered and achieved through careful designing.

D) Architecting interactions

Architecting interactions explores designing for interactions through space in which pace act as a physical interface to stimulate human, analogue and digital interactions. All our actions are nothing but one or the other form of interactions. The process of creating spaces that promote interaction is generally considered as a four staged process. The first three stages of this process happen before the project is delivered whereas the fourth stage comes after the delivery of the project (Hughes, 2017). The process is as follows:

Stage I: involves understanding the design brief, identifying the problem. This is done through consultation from the different stakeholders of the project and taking inputs from them.

Stage 2: involves developing a 'shared vision' with the client. 
Stage 3: involves bringing the vision into reality and the execution of the project.

Stage 4: comes after the delivery of the project. One of the important things to do in this step is observing- it is important to see how people are using the space and reacting to it. This helps in creating a renewed understanding of the project, thus making the process a continuous circular nature.

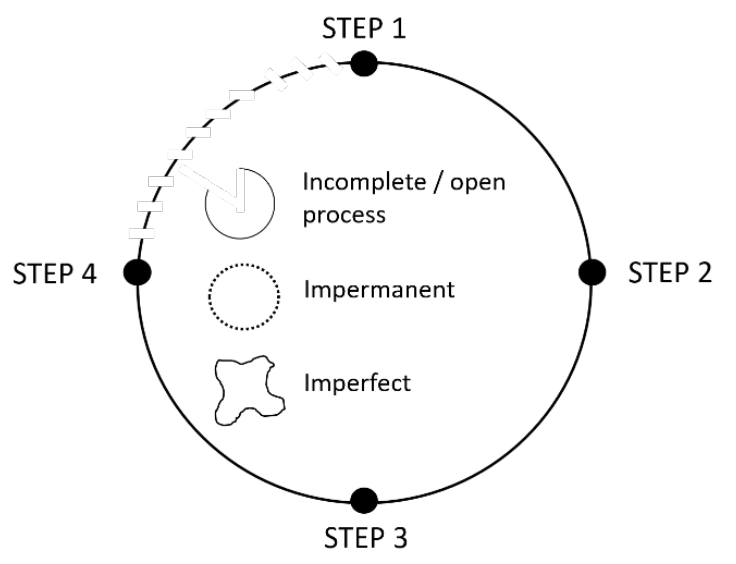

Figure 3. Process of creating Interactions: At any point in time this process is changing, adapting and developing, thus making it impermanent in nature (Source: Author generated sketch)

\section{Urban open spaces in UAE context}

For more than 2000 years, the public open spaces have been a distinct characteristic of the Western cities and for the last 200 years the city planners of European and Northern American cities have ensured to include such spaces with in the city plan with an intention to bring the people closer. In the United Arab Emirates (UAE), the prominent features for public gathering in most traditional communities were Al Musalla which was a large, open space mostly isolated from the residential areas or neighbourhood boundary and located outside the city used for political events, social gatherings, military; Al Masjid or Al Jawamie which had a large central courtyard; Souq (the market); Sahat (plural of Saha) which were open spaces located at a y-shaped junction of two streets within a neighbourhood, dominated by grocery store (Hakim, 1986) to name a few, but since the late 1960s, some of these features have gradually disappeared from the urban planning.

Modern urban design concepts appeared in the mid- $19^{\text {th }}$ century during the colonial era, when establishment of governments, industrialization and the onset of the agricultural revolution led to a considerable amount of development of the Middle Eastern cities (Germeraad, 1990)This subsequently created new infrastructural requirements like increased demand for roads and vehicle accessibility, causing erosion in the open spaces.

Efforts to maintain Arab-Muslim identity increased in the region with the 1960 after the establishment of the Arab League. Nonetheless, the Middle East considers implementing western urban design a developmental necessity (Ezzeddine \& Kashwani, 2019).There has been a transformation in the understanding of public open spaces in the region both in terms of the design concepts and usage. Middle Eastern governments have allowed western concepts to be introduced into cities; including the urban landscape techniques 
and concepts of natural reserves, playgrounds, recreational spaces, managed beach areas, outdoor sports areas, waterfronts, streetscapes, and squares and plazas; as a part of the modernization process.

Enhancing the physical quality of public spaces not only helps in improving liveability but also acts as an active node for people to interact which in turn affects the lifestyle and health conditions of the surrounding population. According to (Katzmann, 2004), a public space experience may reduce depression, enhance contemplativeness, and provide a sense of peace. Contemporary research on the use of public open spaces verifies beliefs about stress-reduction and mental health. Urban and landscape scholars collectively indicated that residents living in communities with common spaces have reported lower levels of stress, aggression, violence with increased sense of belongingness and safety.

\section{I Evaluation of public spaces in Dubai}

Various aspects of a city's open spaces, such as maydan, saha and rahba, have been used in Islamic cities for a long time. Currently these public spaces, which were made with an intention for the people to socialize and interact, are almost neglected in the urban and city planning design strategies implemented in the Middle east cities.

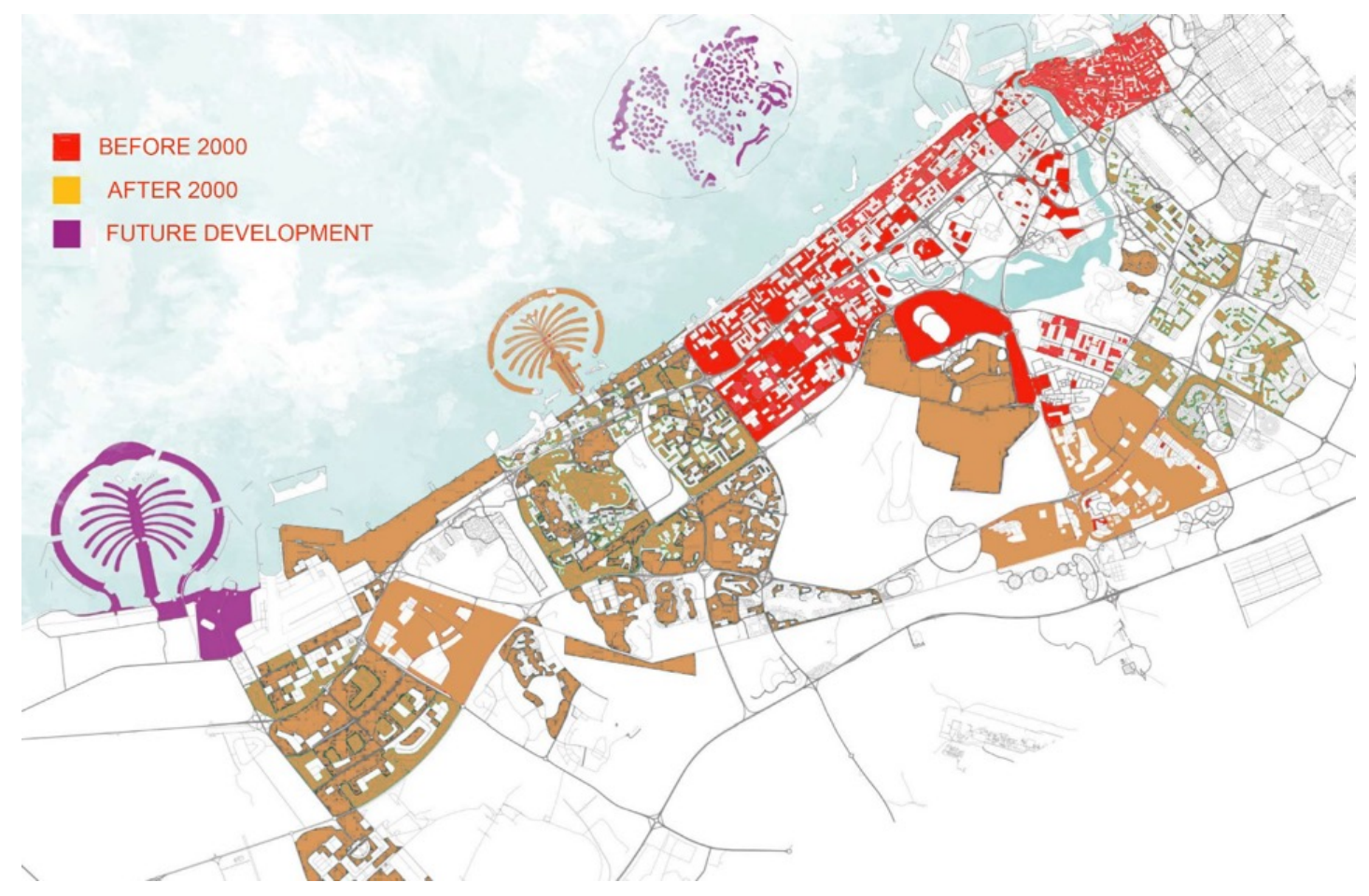

Figure 4. Map showing different phases of Urban development in Dubai (Source: Author generated)

The Emirate of Dubai witnessed two periods of urban development (Figure 4). The first was between the year 1970 and 2000, which represents three decades of conservative urban development. The second phase occurred between $200 \mathrm{I}$ and 20I5, which includes what was call the "Boom" period. During both these phases, there was a shift in the perception of the open spaces at both urban and community level. 
The city of Dubai has grown considerably in the past six decades. Over the time, the city has lost its concept of spaces like saha, al baraha or fereej area which is surrounded by the houses and approached by Sikka (narrow pathways). These historic public spaces were used for entertainment, social collaboration and as market space by the residents within a pedestrian-friendly environment. Al Shindagah and Al Bastakiyah are the two areas in Dubai which still have these spaces till date that were restored by the Dubai Municipality around the end of the 1970s. There is, therefore, a need to understand the nature of the urban spaces that are emerging within the community, to achieve inclusive and liveable neighbourhoods. Similarly, urban planning has transformed the old community open space to either a commercial intersection of main roads which is dominated by vehicle movement or have been put under use as parking lots to serve the trading domain (Ezzeddine, 2014). As a result, the public open spaces had been converted from social spaces that were characterized by vibrant, lively interaction into areas supporting the infrastructure needs and the transportation within the city. To understand the current nature of these spaces in the year 2020, the author conducted various case studies as a part of the research, which is discussed in the section below.

\subsection{Case studies}

The various tools used to conduct this research are quantitative in nature. Three different sites were selected for the study which are Dubai water Canal, Dubai Marina Walk and Community Park in a small residential area in Remraam, Dubai. These case studies have been selected; keeping in mind various parameters like location (sites from both new and old Dubai area), hierarchy in terms of size, dominant land-use of the surrounding areas and the dominant user groups; to get a holistic understanding of the diverse nature of the public open spaces in the UAE (Table 2).

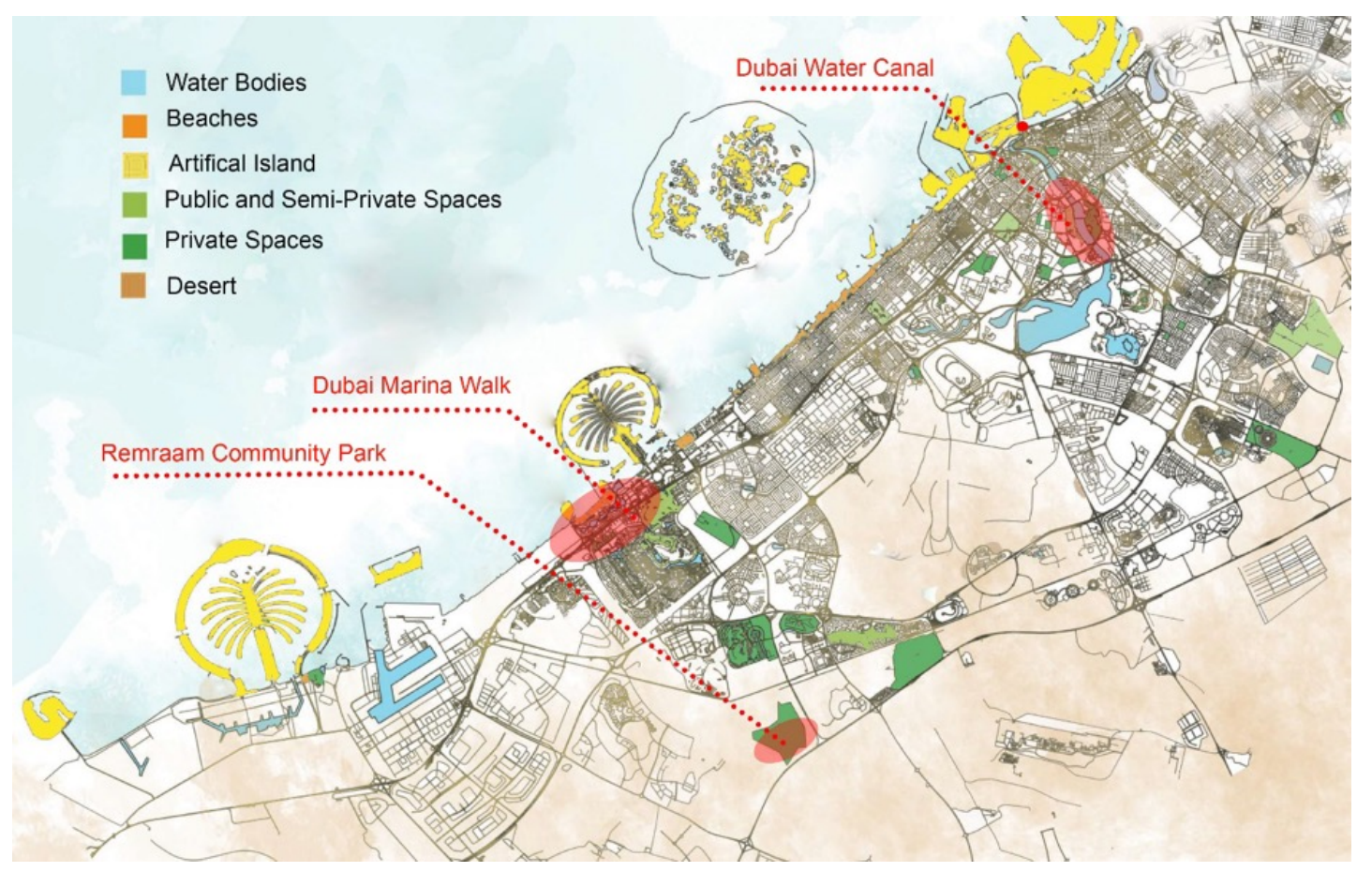

Figure 5. Map depicting the location of the case study selected for the research

(Source: Author generated) 
Table 2: Selection criteria and public open spaces selected for the study (Source: Author generated)

\begin{tabular}{l|l|l|l} 
Parameter & Water Canal Dubai & $\begin{array}{l}\text { Dubai Marina } \\
\text { Walk }\end{array}$ & $\begin{array}{l}\text { Remraam } \\
\text { Community Park }\end{array}$ \\
\hline Hierarchy & City Level & Community Level & Neighbourhood level \\
\hline $\begin{array}{l}\text { Dominant land- } \\
\text { use of the } \\
\text { surrounding }\end{array}$ & $\begin{array}{l}\text { Mixed-Use and } \\
\text { commercial stretch connecting } \\
\text { old Dubai and New Dubai }\end{array}$ & Mixed land-use & Residential Community \\
\hline $\begin{array}{l}\text { Development } \\
\text { authority }\end{array}$ & $\begin{array}{l}\text { Meraas Holding \& Maidan } \\
\text { Group (Govt. owned) }\end{array}$ & $\begin{array}{l}\text { Emaar Group } \\
\text { (Private Group) }\end{array}$ & $\begin{array}{l}\text { Dubai Properties } \\
\text { (Private Group) }\end{array}$ \\
\hline $\begin{array}{l}\text { Ownership } \\
\text { Dominant user } \\
\text { group }\end{array}$ & $\begin{array}{l}\text { Tourist's Place of interest and } \\
\text { recreational space }\end{array}$ & High Income group & $\begin{array}{l}\text { Middle and high-income } \\
\text { group }\end{array}$ \\
\hline & & Private &
\end{tabular}

\subsubsection{Dubai Water Canal}

The $3.2 \mathrm{~km}$ long and 80 to $120 \mathrm{~m}$ in width water canal Dubai cuts through Dubai's main artery; the Sheikh Zayed Road across Safa Park; creates 80,000 sqm for public space which includes various facilities like $3 \mathrm{~km}$ running track, $12 \mathrm{~km}$ cycling path. It stretches from the old Creek and passes through the Design District and Business Bay to join back in the Arabian Gulf. On the course, it also cuts across the Sheikh Zayed Road. Apart from being a tourist attraction in the city, the canal also functions as a means of transport. One of the prominent features of this site is a mechanical waterfall- a motion-operated water pumps which creates an illusion of throwing water over the bridge in a constant flow, illuminated by multi-coloured lights. This spectacle is visible from the promenade, and automatically gets switched off when boat is detected in closed proximity by the sensors installed. Out of five, three pedestrian bridges provide access to the visitors across the canal at key nodes. Being at the centre of the downtown Apart from connectivity these bridges provide stunning vistas of the Dubai skyline and of the water vessels below.

Dubai Water Canal is noteworthy for its excellent environmental friendliness. The 12 kilometer cycling track offers a risk-free and beckoning spot for riders, away from the traffic. Hundreds of street lamps and decoration lights across the water canal are powered by solar panels that charge up during the day time. These lamp posts also have mobile charging stations in them providing both safety and functionality to the users. The design is fluid and inviting in nature with spaces which allow people to approach one another. Apart from physical connectivity through pedestrian walkways, visual connectivity between different function areas and nodes also plays a key role in fostering interactions among the visitors. 


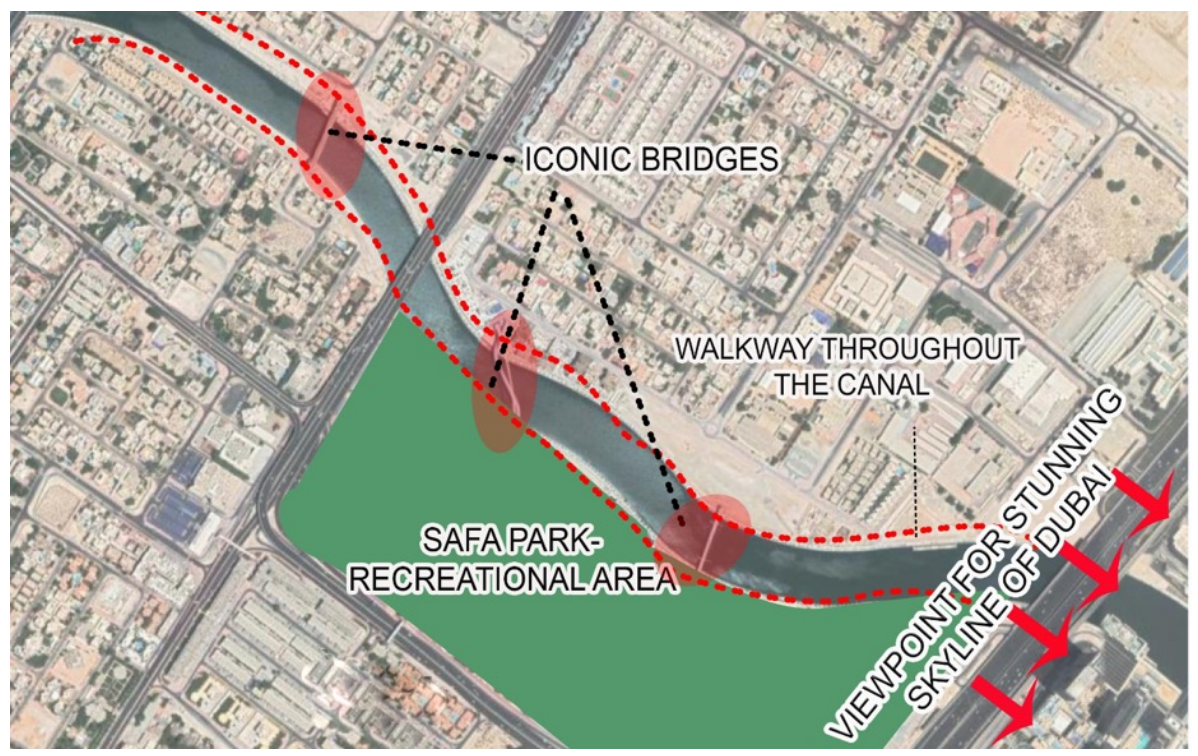

Figure 6. Dubai Water Canal and prominent features (Source: Author generated illustration)
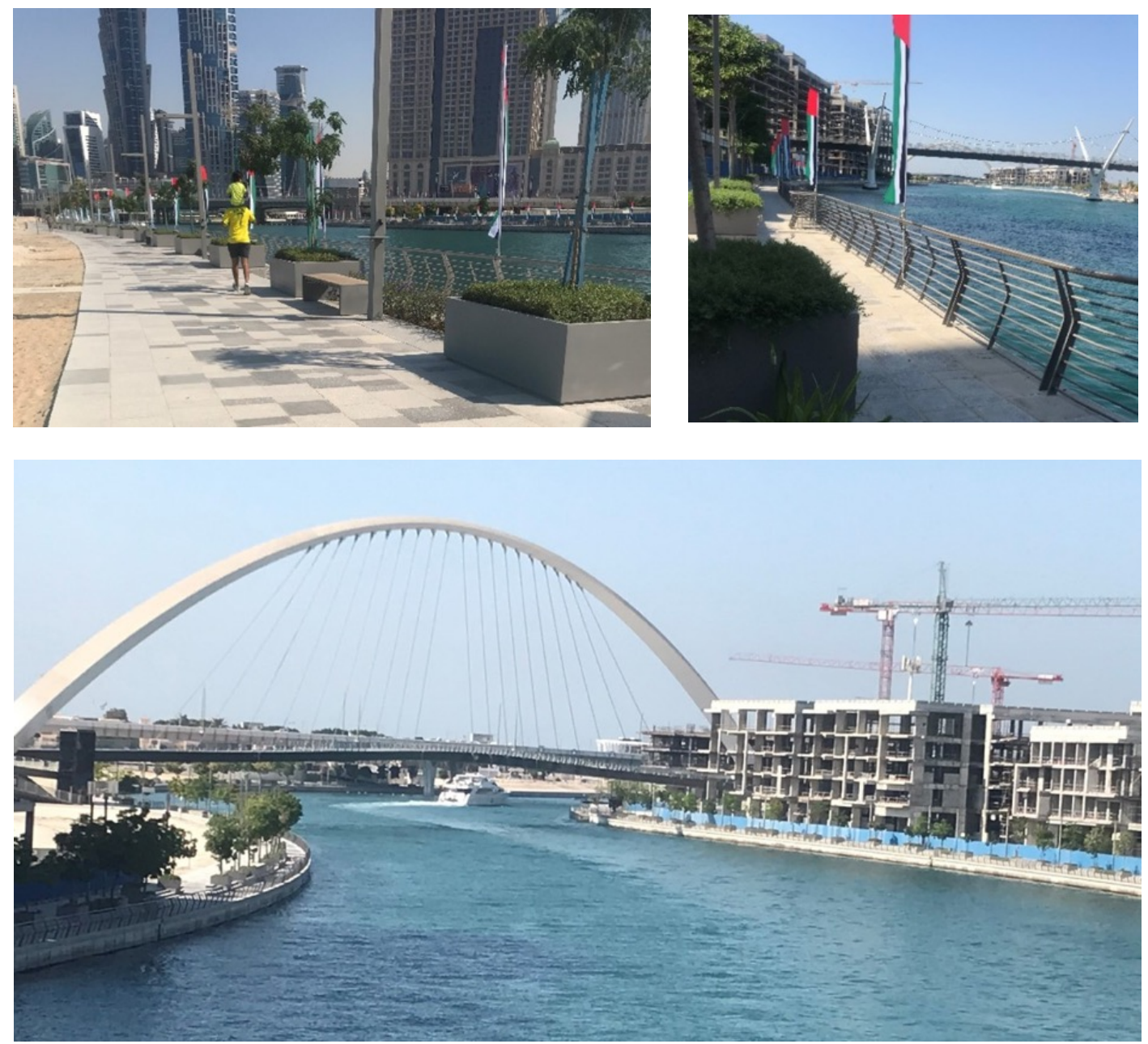

Figure 7, 8, 9: Prominent features across Water Canal (Source: Author's Photograph) 


\subsubsection{Marina Walk Dubai}

Dubai marina is a mixed-use development of over 150.000 residents where manmade water canal plays a central role and focus for each element of the area. Site area of Dubai Marina is I, I 40 acres of which I $2 \%$ of the area is in the form of Waterways and Marina keeping in mind the concept of a 'city within the city' to shift the perceived centre of Dubai further along the shore of the Gulf.

Marina Walk is a pedestrian promenade, a stretch of around $8 \mathrm{~km}$, comprises of sophisticated Urban centres of office tower on above floor with retail and entertainment fronting the pedestrian walkway. Restaurant, hotel and performing art centre is a cultural heart of the community.

The mixed-use development is planned with the aim of creating a new focus for highdensity development establishing a continuous, $15 \mathrm{~m}$-wide strip of land around its perimeter. This central public space covers around $12 \%$ of the total land area of the site. Although much of this area is occupied by the marina water surface, it also includes landscaped public walkways, creating a recreational zone along the waterfront with views into the various water basins and a closer relationship with the water. In addition to the marina waterway and promenade, the important components of the public realm are the streets, avenues, and parks, which together create the framework for the development. The main access to the site is through a series of boulevards which are skilfully landscaped to create stunning vignettes. Residential building entrances are provided in a way to encourage active pedestrian circulation and to create functional and visual links between the buildings and the marina.

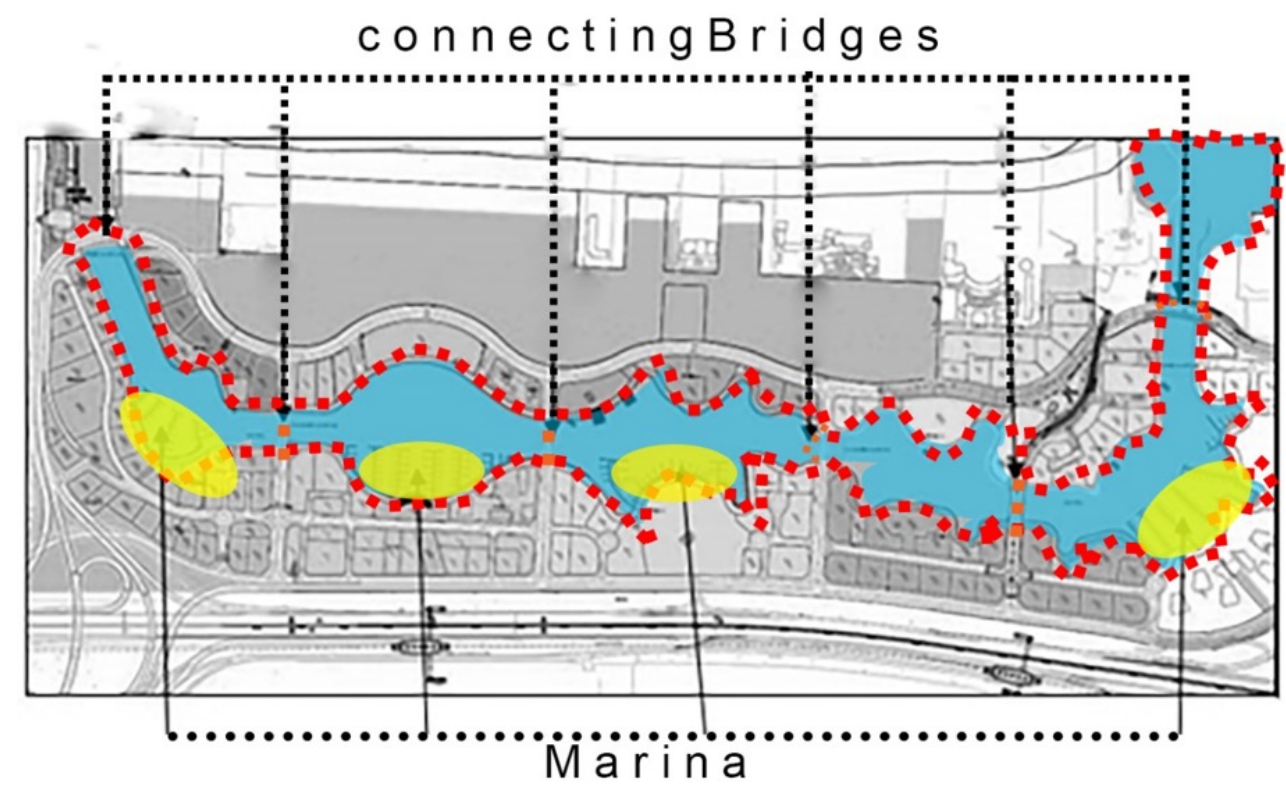

Figure 7: Map showing Marina Walk and connecting bridges with prominent recreational zones (Source: Author generated illustration) 

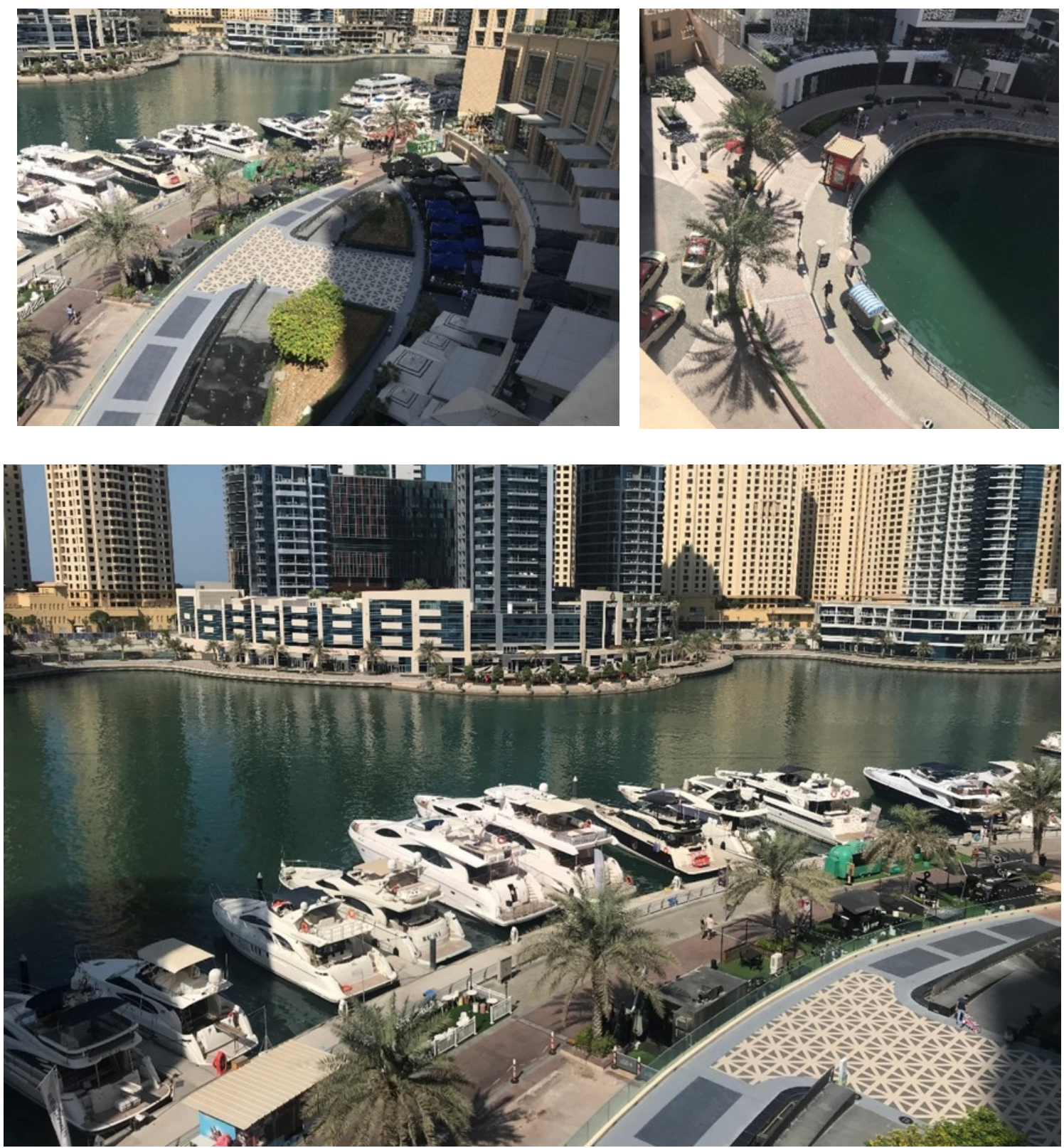

Figure II, 12, 13. Prominent features across Marina Walk (Source: Author's Photograph)

Shopping areas and facilities like restaurants and cafes are strategically located along the promenade around the perimeter of the marina and along major boulevards. All residential development is within a five-minute walk of the marina promenade. The detailed design of the promenade frontage, with its convertible retail arcade that opens in winter and closes for climate control in summer, and its pedestrian connections between the residential buildings and the waterfront, has been a prominent consideration throughout the development. This creates new standards for the pedestrian environment in terms of quality and character as it facilitates interactions and connectivity throughout the perimeter.

Dubai Marina also promotes a sense of community and inclusiveness that celebrates the region's natural and cultural resources. As Dubai continues to prosper and grows, the 
project's compelling public spaces and thoughtful urban design serves as a permanent source of ideas and inspiration for future developments around the city.

\subsubsection{Community park - Remraam, Dubai}

Remraam community located in Dubailand is known for its natural view and greenery which offers its residents a mix of nature and artificial landscape. Thoughtfully designed, it offers a perfect balance of serenity as well as accessibility to different functional spaces in the community via a large central garden and play areas. Various facilities and features like walking tracks, basketball, tennis courts, swimming pool, kids play area acts as active nodes to attract the residents in turn providing a context for them to socialize and interact with each other.

Along with the central garden the design has 37 building podiums with open sitting spaces, gazebo's, sand pit for kids, swings and designated places for small gathering with barbeque facilities. Basic amenities like supermarkets, pharmacy, salon and food joints also acts as catalyst to attract people and act as active nodes for socializing. The central park is used for various types of outdoor activities like food festivals, competitions, Halloween and Christmas celebrations, pool parties and movie nights; the events are designed to bring the community together and create a place which brings a sense of belongingness to its residents.

Based on the multiple site visits done to the selected sites and the information gathered during the course of the study; the table below shows the analysis of the three selected case studies based on the different indicators and parameters that are considered important for providing context for interaction or helps in fostering it among the users or visitors in public open spaces (identified through the literature study).

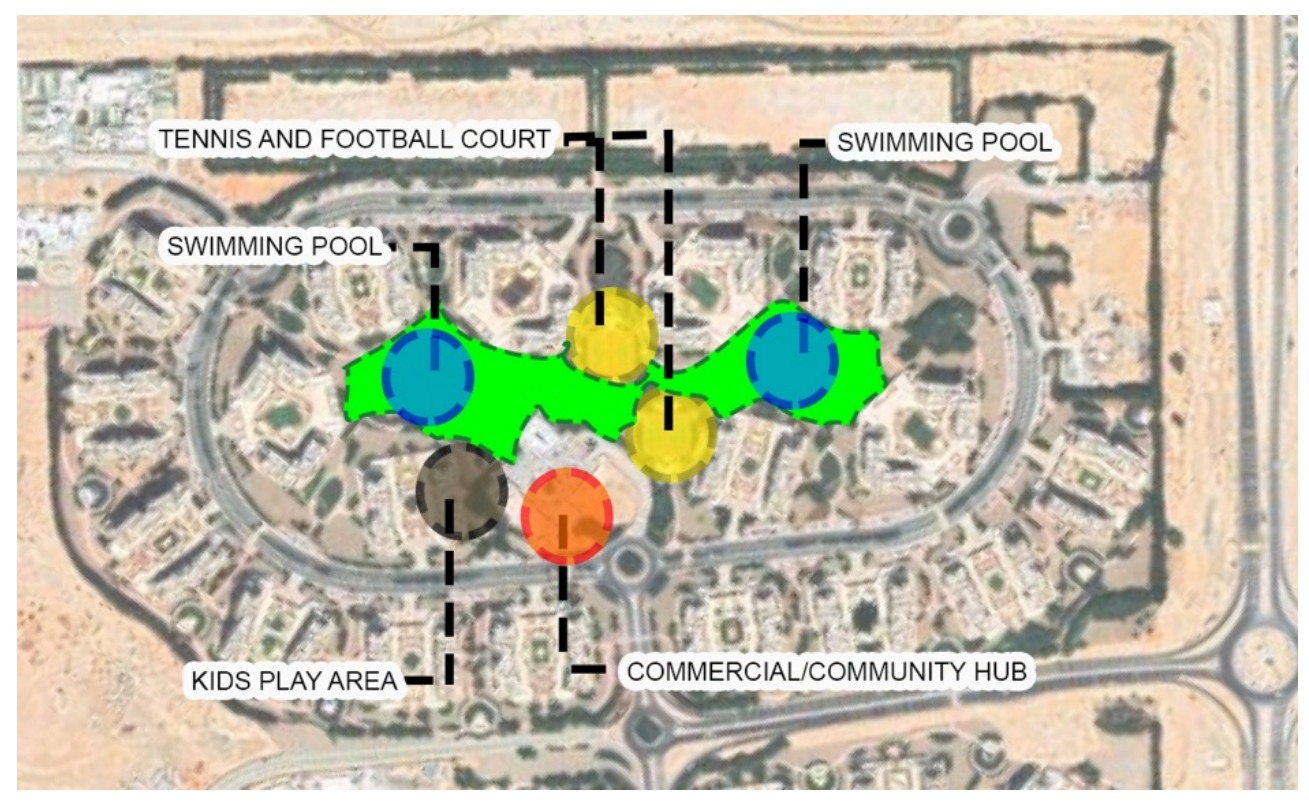

Figure 8. Key plan showing various facilities provided in the open space in the community area of the residential development (Source: Author generated illustration) 

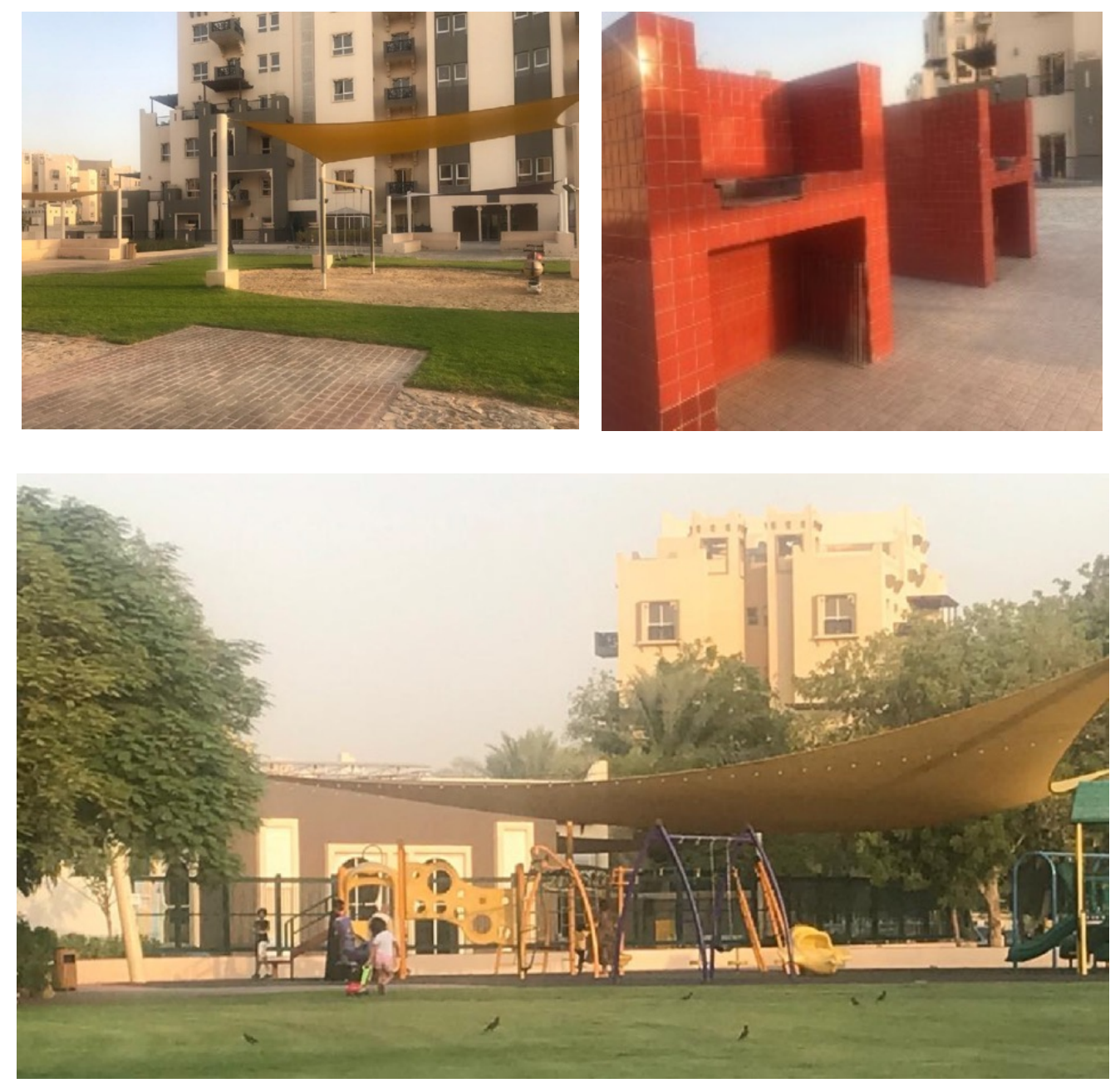

Figure 15, 16, 17. Prominent facilities in Remraam community area (Source: Author photograph)

\section{Discussion}

Consistent urbanization, demographic, and economic growth alongside, land privatization process have progressively transformed the nature and use of public open spaces within the UAE. The remaining squares and plazas in the UAE, which were places for social gathering or public entertainment, no longer hold true to their nature and have now been converted to roads and street intersections or have been deconstructed into parking lots. Until the mid-1980s, there was an increase in eradication of squares (one of the prominent public open spaces in the past) all over cities of the UAE (Ezzeddine \& Kashwani, 2019).Thus, creating a clear gap in the development of these public open spaces where some of them are left underutilized and others were claimed for infrastructural developments.

The key problem identified in the study is that the process of urbanization in the UAE; since the discovery of oil; has led to the loss of open public spaces, with consistent weakening of social coherence and stability, accompanied by ignorance of sustainability in the longer term. The public open spaces have been converted from social spaces that were characterized by vibrant, lively interaction into areas supporting the infrastructure needs and the transportation within the city. 
Table 3: Comparative analysis of the sites selected for the study on the basis of various parameters which helps in fostering interaction among the users (Source: Author generated)

\begin{tabular}{|c|c|c|c|}
\hline Parameters & Dubai Canal & Dubai Marina & $\begin{array}{l}\text { Community Park - } \\
\text { Remraam }\end{array}$ \\
\hline $\begin{array}{l}\text { Connecting } \\
\text { People }\end{array}$ & $\begin{array}{l}\text { By providing facilities like } \\
\text { pedestrian pathways, } \\
\text { Cycling tracks and } \\
\text { aesthetically pleasing } \\
\text { vignette. }\end{array}$ & $\begin{array}{l}\text { By providing facilities like } \\
\text { pedestrian pathways, Yacht } \\
\text { facilities, by integrating common } \\
\text { sitting spaces, gazebo, and } \\
\text { restaurants with outdoor sitting } \\
\text { facilities. }\end{array}$ & $\begin{array}{l}\text { Pocket park at podium level and } \\
\text { ground for each building with } \\
\text { barbeque and children play area } \\
\text { promoting social interaction. } \\
\text { Community park with swimming } \\
\text { pools, tennis court and football } \\
\text { court along with kids play area } \\
\text { and open green space provides } \\
\text { place for many community level } \\
\text { events. }\end{array}$ \\
\hline $\begin{array}{l}\text { Accessibility } \\
\text { and } \\
\text { Proximity }\end{array}$ & $\begin{array}{l}\text { Canal works as a } \\
\text { connection between new } \\
\text { Dubai and old Dubai. } \\
\text { In proximity to prominent } \\
\text { areas like Safa Park, } \\
\text { Medcare hospital, JW } \\
\text { Marriott. }\end{array}$ & $\begin{array}{l}\text { Dubai tram Connectivity with } \\
\text { prominent areas like JLT, JBR } \\
\text { Beach and JBR walk. } \\
\text { Interaction nodes within the } \\
\text { space connectivity of each } \\
\text { residential streets with the Maria } \\
\text { walk }\end{array}$ & $\begin{array}{l}\text { Accessible to prominent } \\
\text { surrounding areas like Dubai } \\
\text { sports city and Dubai motor city. } \\
\text { Basic amenities like open } \\
\text { restaurant, Caffe, supermarket, } \\
\text { pharmacy to fulfil individual need } \\
\text { of the residents }\end{array}$ \\
\hline \multirow{3}{*}{$\begin{array}{l}\text { Visual } \\
\text { connectivity }\end{array}$} & $\begin{array}{l}\text { Direct visual connection } \\
\text { to various facilities from } \\
\text { prominent nodes }\end{array}$ & $\begin{array}{l}\text { Direct visual connection to } \\
\text { various facilities from prominent } \\
\text { nodes } \\
\text { connecting Bridges }\end{array}$ & $\begin{array}{l}\text { Direct visual connection to } \\
\text { various facilities from prominent } \\
\text { nodes } \\
\text { Swimming Pool- }\end{array}$ \\
\hline & 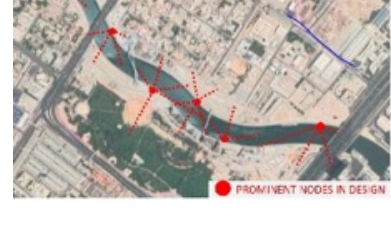 & 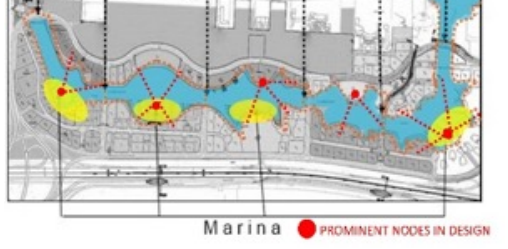 & 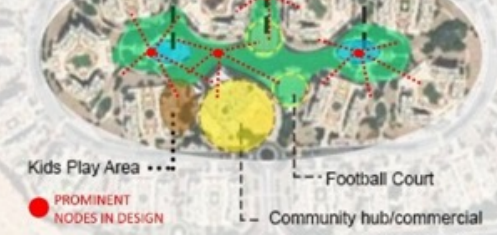 \\
\hline & Figure 18 & Figure 19 & Figure 20 \\
\hline $\begin{array}{l}\text { Eye level } \\
\text { design }\end{array}$ & Yes & Yes & Yes \\
\hline Lighting & Yes & Yes & Yes \\
\hline $\begin{array}{l}\text { Multipurpos } \\
\text { e and multi- } \\
\text { functional } \\
\text { spaces }\end{array}$ & $\begin{array}{l}\text { Mobile charging stations } \\
\text { at lamp posts. Connecting } \\
\text { bridges at prominent } \\
\text { areas where bridges itself } \\
\text { has its own importance }\end{array}$ & $\begin{array}{l}\text { Entertainment, restaurant, and } \\
\text { cultural art centre fronting the } \\
\text { pedestrian walkway creating } \\
\text { different types of gathering places. }\end{array}$ & $\begin{array}{l}\text { Central park and gazebos used } \\
\text { for various small-scale events and } \\
\text { parties. }\end{array}$ \\
\hline
\end{tabular}




\begin{tabular}{|c|c|c|c|}
\hline $\begin{array}{l}\text { Facilitate } \\
\text { the } \\
\text { unexpected }\end{array}$ & $\begin{array}{l}\text { Motion-operated water } \\
\text { wonder pumps, water } \\
\text { through the bridge in a } \\
\text { constant flow, visible from } \\
\text { the promenade, and can } \\
\text { be switched off when a } \\
\text { sensor detects a boat } \\
\text { nearby. }\end{array}$ & - & $\begin{array}{l}\text { Central park and gazebos used } \\
\text { for various small-scale events and } \\
\text { parties. }\end{array}$ \\
\hline Comfort & Yes & Yes & Yes \\
\hline $\begin{array}{l}\text { Social } \\
\text { Inclusion }\end{array}$ & $\begin{array}{l}\text { Apart from the facilities } \\
\text { and civic attractions } \\
\text { provided at the site, the } \\
\text { space further strengthens } \\
\text { social inclusion by acting } \\
\text { as the arena/ platform for } \\
\text { cycle racing, marathons } \\
\text { (Dubai Canal run) and } \\
\text { other events organized by } \\
\text { Ministry of Health and } \\
\text { Prevention- UAE }\end{array}$ & $\begin{array}{l}\text { The space facilitates social } \\
\text { inclusion by successfully } \\
\text { integrating activities like Dubai } \\
\text { International Boat show, street } \\
\text { art and performances, cultural } \\
\text { events like 'The spirit of the } \\
\text { union' which attract a diverse } \\
\text { group of users to the site. }\end{array}$ & $\begin{array}{l}\text { The community frequently } \\
\text { organises festivities to celebrate } \\
\text { festivals and important dates } \\
\text { from all cultures and ethnicities } \\
\text { in the community park. Fun } \\
\text { activities for kids and grown-ups } \\
\text { in the form of movie nights, small } \\
\text { scaled fairs, potlucks etc. are } \\
\text { frequently a part of the } \\
\text { community's yearly event } \\
\text { calendar. }\end{array}$ \\
\hline
\end{tabular}

A consequence of this was that the social fabric of community life was eroded. Despite support from the UAE leadership and regulatory authorities for developing sustainable communities in line with global compacts, the gap between social life and community urban planning was yet to be filled.

Cities and communities in the Arab world inevitably faced urban transformation, driven by the global context in which cities are being reshaped, and the modernization of urban planning themes. There has been a change in the understanding of public open spaces in the region both in terms of the design concepts and usage.

Middle Eastern governments have allowed western concepts to be introduced into cities; including the urban landscape techniques and concepts of natural reserves, playgrounds, recreational spaces, managed beach areas, outdoor sports areas, waterfronts, streetscapes, and squares and plazas; as a part of the modernization process.

Social well-being evolves from a sense of security, belonging, familiarity, support, cohesion, and integration of social groups, based on respect for different cultures, traditions, and backgrounds. Based on these approaches, the researcher appreciates the new urban planning policies adopted by decision-makers and urban planners in the UAE to develop open spaces in the new community master plans which regulates and includes new design guidelines.

Looking at the new developments in the past few years and the upcoming projects it is evident that the ongoing regeneration of public open spaces in cities of the UAE is taking multiple factors into consideration during the design stages, including the proximity, aesthetics and attractiveness of the location of the space; its accessibility by all population groups along with meeting the requirements of disabled and elderly people. However, this study also hints at an optimistic future for the development and management of such public spaces. It appears that it is not just the physical environment and accessibility that encourages or discourages people to come out such places in public, but also the purpose, use, facilities provided and an opportunity to explore new and distinctive vignettes in a comfortable and adaptive environment. 


\section{Conclusion and recommendation}

The author recommends that the potential public spaces as well as the existing underutilized open spaces should be developed/redeveloped to intensify their use. The gap between the existing and the requisite open spaces (according to the standards) of all hierarchical levels should be bridged. Since the economic value of land encompassed within the municipal planning is high, it is pivotal that open spaces which are multifunctional in nature should preferably be developed.

The author further recommends that the remaining gap in some of the existing spaces can be bridged through local mitigation of urban temperatures in summer; eye level design; increasing inclusiveness; providing active nodes in design which acts as areas that attract the users in turn giving context for interactions; creating multipurpose and multifunctional spaces; use of eco-friendly materials; ensuring comfort and a sense of safety; reuse of old elements; and using structural techniques and materials that display long durability and resistance to outdoor conditions. These factors can further lay a strong foundation for designing such spaces within the UAE. Meeting all these factors widens the level of interaction among the city dwellers. However, this crucially requires carefully planned strategies and policy models.

\section{References}

Bourke, V. J. (1962) Rationalism. In Runes, D. D. (ed.), Dictionary of Philosophy. Totowa, NJ: Littlefield, Adams, and Company, p. 263.

Dewey, J. (2003) Human nature and conduct. 2 I ed. Mineola, New York: Dower Publications Inc.

Ezzeddine, I. \& Kashwani, G. (2019) Public Squares in UAE Sustainable Urbanism: Social Interaction \& Vibrant Environment.

Garau at al. (2013) The Charter of Public Space. Biennale Spazio Pubblico and UN-Habitat

[Online] Available at: http://www.biennalespaziopubblico.it/outputs/the-charter-of-public-space

Gehl, J. (1987) Life between buildings: using public space. New York: Van Nostrand Reinhold.

Germeraad, P. (1990) Open space in human settlements: The lesson from the Islamic tradition contemporary design consideration for open spaces in Arab-Muslim human settlements in the Middle East. Germeraad. https://edepot.wur.nl/202850

Gruen, V. \&. Smith L. (1960) Shopping towns, U.S.A: The, New York: Van Nostrand.

Hakim, B. ( 1986$)$. Arabic-Islamic cities: Building and planning principles. London: KPI.

Holl, S., Pallasmaa, J. Alberto Perez, G. (2007). Questions of Perception: Phenomenology of Architecture. 2nd edition ed. San Francisco: William K Stout Publisher.

Hughes, S. A. (2017) Architecting Interaction: How to innovate through interaction. Pumbo.

Yarwood, J. (20II) Urban planning in the Middle East: Case studies.. Cambridge: Cambridge Scholars Publishing.

Katzmann, R. (2004) The intellectual in public life. Washington, D.C.: Woodrow Wilson Center Press.

Maslow, A. H. (1954) Motivation and Personality. First edition ed. s.l.: New York, Harper.

Mounin, G. (1980). Semiotic Praxis: Studies in Pertinence and in the means of expressions and communication, New York: Plenum Press.

Norberg-Schulz, C. (1980) Introduction. Genius Loci: towards a Phenomenology of Architecture. New York: Rizzoli.

Tibbalds, F. (2004) Making people-friendly towns. London, New York: Taylor \& Francis. 